\title{
Quality Characteristics of Livestock Feces Composts Commercially Produced in Gyeonggi Province in 2008
}

\author{
Chang-Sung Kang* and An-Sung Roh \\ Gyeonggido Agricultural Research \& Extension Services, Gyeonggi-do Whaseong-si Gisan-ro 31-22, 445-784
}

\begin{abstract}
This survey was conducted to promote the environment-friendly use and recycling of livestock feces by obtaining information about the current state of livestock feces composts manufactured in Gyeonggi Province. Therefore, some aspects of quality and manufacturing techniques of livestock feces composts (LFCs) were examined especially in relation to the LFCs quality standard (LQS). By surveying the 70 composting plants in Gyeonggi Province, the total commercial production of LFCs in 2008 was estimated to be about $480,000 \mathrm{Mg}$ year $^{-1}$ and they were manufactured mainly by using both mechanical mixer and bottom air blower. LFCs were composed mainly of chicken feces $\mathbf{2 9 . 2} \%$, pig+chicken feces $\mathbf{2 3 . 1} \%$, pig feces $\mathbf{2 0 . 0} \%$, livestock feces+oil cake $12.3 \%$, pig+chicken+cattle feces $10.8 \%$ and pig+cattle feces $4.6 \%$ On the basis of the current official standard which was revised on March 2010, 11 composts out of surveyed 76 ones did not meet the LQS due to inadequate content of water(5), $\mathrm{OM} / \mathrm{N} \mathrm{(1),} \mathrm{NaCl}(2)$ and $\mathrm{Zn}(3)$. The satisfaction rate to $\mathrm{LQS}$ by manufacturers was $100 \%$ in the composts produced by farmer's cooperative societies, $80.7 \%$ by civil factories, and $44.4 \%$ by farming guilds, respectively. The $\mathrm{OM} / \mathrm{N}$ declined by adding chicken feces and oil cake, while $\mathrm{Ca}$ content was increased by the addition of chicken feces and $\mathrm{NaCl}$ was increased by adding cattle feces.
\end{abstract}

Key words: Livestock feces, Compost, Compost quality, Compost manufacture

\section{Introduction}

Gyeonggi Province surrounding Seoul is the largest area of livestock industry in Korea. In 2009, Gyeonggi Province produced livestock feces amounting to about $8.3 \mathrm{Tg}$ which was $20 \%$ of the total production in Korea. Therefore, the environment-friendly management of livestock feces is one of the greatest issues in order to preserve the rural environment in this area. Livestock feces is one of the important materials as an organic source for arable land. There are lots of reports on the application effects of livestock compost into arable soil (Yang et al., 2007; Jun et al, 2003; Jung, 2002; Song et al., 2001; Jo and Lee, 2001; Yun et al., 1996), and some other ones about determining the application rate of livestock compost for crop cultivation (Kim and Jung, 2000; Lee et al., 1999; Shayya et al., 1993). In this regards, the quality of livestock compost has been emphasized and the relevant official standard has been revised more strictly. In Korea, there has been an official quality standard of

\footnotetext{
Received : March 17. 2011 Accepted : April 14. 2011

*Corresponding author : Phone: +82312295821

E-mail: cskang@gg.go.kr
}

commercial LFCs and the current official standard was revised in March 2010. The main factors of livestock compost quality standard (LQS) are the contents of water, organic matter, inorganic matter, $\mathrm{NaCl}$ and heavy metals, and the ratio of $\mathrm{OM} / \mathrm{N}$, etc. This survey was conducted to promote the environment-friendly recycling or use of livestock feces by obtaining information about the current state of livestock feces compost manufactured in Gyeonggi Province. Therefore, some aspects of quality and manufacturing techniques of LFCs were examined especially in relation to the LQS.

\section{Materials and Methods}

76 samples of commercial livestock feces composts (LFCs) were collected at the warehouse of 70 compostmanufacturing plants located in Gyeonggi Province where approximately 100 of commercial LFC manufacturing plants were in operation. The current production state of some LFC manufacturing plants was examined by questionnaire survey and LFC quality factors such as OM, OM/N, T-N, $\mathrm{P}_{2} \mathrm{O}_{5}, \mathrm{~K}_{2} \mathrm{O}, \mathrm{CaO}, \mathrm{MgO}, \mathrm{Na}_{2} \mathrm{O}, \mathrm{NaCl}$, water content, and heavy metals $(\mathrm{Cu}, \mathrm{Zn}, \mathrm{Cd}, \mathrm{As}, \mathrm{Cr}$, 
$\mathrm{Ni}, \mathrm{Pb}, \mathrm{Hg}$ ) were analyzed by soil and plant analysis method recommended by the National Institute of Agricultural Science and Technology in Korea. Some analysis methods used in this study were as follows. Organic matter was determined by ashing method measuring a loss in weight. Nitrogen was obtained by Kjeldahl method after decomposing samples with conc. sulfuric acid. Cations such as potassium, calcium, magnesium and sodium were analyzed by decomposing them with strong acid (perchloric acid $9+$ sulphuric acid 1) and determined by inductively coupled plasma spectrophotometer (ICP, GBC Integra XMP, Australia). Heavy metals except mercury were measured by decomposing them with nitric acid in microwave (Tekton Qwave 2000, Canada) and analyzed by ICP, and mercury was directly analyzed by mercury analyzer (Leco AMA254, USA).

\section{Results and Discussion}

The total production of livestock compost products was estimated to be about $480,000 \mathrm{Mg}$ year $^{-1}$ by surveying 70 plants and they were manufactured mainly by using mechanical mixer and bottom air blower. Major components of surveyed compost products were in the order of chicken feces $29.2 \%$, pig+chicken feces $23.1 \%$, pig feces $20.0 \%$, livestock feces+oil cake $12.3 \%$, pig+ chicken+cattle feces $10.8 \%$ and pig+cattle feces $4.6 \%$ (Table. 1).

Chemical properties of 76 composts produced in Gyeonggi Province in 2008 were as follows; $41.8 \pm$ $7.8 \%$ of $\mathrm{OM}, 29.2 \pm 7.5$ of $\mathrm{OM} / \mathrm{N}, 1.53 \pm 0.51 \%$ of T-N, $1.98 \pm 0.81 \%$ of $\mathrm{P}_{2} \mathrm{O}_{5}, 1.46 \pm 0.57 \%$ of $\mathrm{K}_{2} \mathrm{O}, 4.48$ $\pm 1.95 \%$ of $\mathrm{CaO}, 0.87 \pm 0.41 \%$ of $\mathrm{NaCl}, 37.9 \pm 11.6 \%$ of water and $16.0 \pm 2.8$ of compost quality score (Table. 2).

On the basis of the current official standard which was revised in March 2010, 60 composts out of 76 composts surveyed in this study met the LQS and 5 products met the general compost standard, while 11 products did not meet the compost standard due to the violation of content limit in water (5), OM/N (1), NaCl (2) and $\mathrm{Zn}$ (3). But the violation in water content practically does not matter since it changes over the time during storage period. Consequently, the composts having problem in terms of chemical properties were 5 products, accounting for $6.6 \%$ of all the surveyed ones.

As for the compost quality by manufacturers, all the 10 composts produced by farmer's cooperative societies met the LQS and 50 percent of them was the first grade in quality degree and the rest was the second grade. Forty-six composts out of 57 (80.7\%) made by civil factories met the LQS and the first grade in quality

Table 1. Share and component ratio by raw materials of livestock composts.

\begin{tabular}{|c|c|c|c|c|c|c|}
\hline Raw materials $^{\dagger}$ & $\mathrm{P}$ & $\mathrm{Ch}$ & $\mathrm{P}+\mathrm{Ch}$ & $\mathrm{P}+\mathrm{Ca}$ & $\mathrm{P}+\mathrm{Ch}+\mathrm{Ca}$ & $\mathrm{Li}+\mathrm{O}$ \\
\hline Share $(\%)$ & 20.0 & 29.2 & 23.1 & 4.6 & 10.8 & 12.3 \\
\hline Component & P-S & $\mathrm{Ch}-\mathrm{S}$ & P-Ch-S & P-Ca-S & P-Ch-Ca-S & P-Ch-Ca-S-O \\
\hline Ratio (\%) & $57-43$ & $64-36$ & $31-32-37$ & $38-32-30$ & $35-14-24-27$ & $18-6-29-24-23$ \\
\hline
\end{tabular}

${ }^{\dagger} \mathrm{P}$; pig feces, Ch; chicken feces, $\mathrm{Ca}$; cattle feces, Li; livestock feces, O; oil cake, S; sawdust.

Table 2. Chemical properties of composts produced in Gyeonggi Province in 2008.

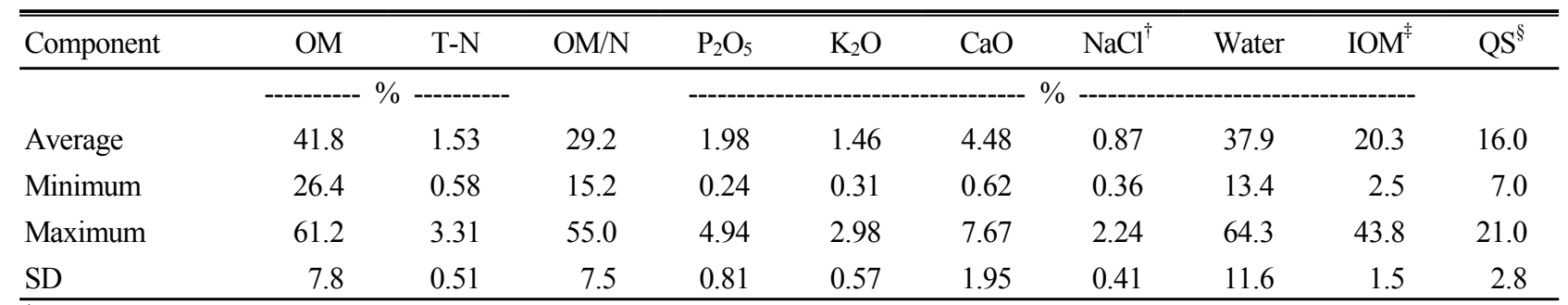

${ }^{\dagger} \mathrm{NaCl}$ content; dry weight basis (others; fresh weight basis).

${ }^{\ddagger} \mathrm{IOM}$; inorganic matter content.

${ }^{\S} \mathrm{QS}$; quality score of compost, 1-23 (degree by scores $17-231^{\text {st }}, 12-162^{\text {nd }}$, below $113^{\text {rd }}$ ).

- Quality component; OM (1-9, above 25\%), IOM (1-9, below 55\%), Water (1-5, below 55\%)

${ }^{9}$ Heavy metal content (mg kg-1, DW, data is not shown in the table); $\mathrm{Cu} 117.5 \pm 73.4$ (22.4-379.2), Zn $457.2 \pm 241.9$

$(97.1-1445.4)$ 
Table 3. Quality degree distribution of composts by the types of manufacturers.

\begin{tabular}{lccccc}
\hline \hline \multicolumn{2}{l}{ Quality degree of compost } & Sum & $\begin{array}{c}\text { Farmer's coop- } \\
\text { erative society }\end{array}$ & Farming guild & Civil \\
\hline Sum & & $76(100)$ & $10(100)$ & $9(100)$ & $57(100)$ \\
\hline \multirow{2}{*}{ Livestock } & $1^{\text {st }}$ grade & $26(34.2)$ & $5(50)$ & $2(22.2)$ & $19(33.3)$ \\
compost & $2^{\text {nd }}$ grade & $30(39.5)$ & $5(50)$ & $2(22.2)$ & $23(40.4)$ \\
& $3^{\text {rd }}$ grade & $4(5.3)$ & $0(0)$ & $0(0)$ & $4(7.0)$ \\
\hline \multicolumn{2}{l}{ General compost } & $5(6.6)$ & $0(0)$ & $3(33.3)$ & $3(5.3)$ \\
\hline \multicolumn{2}{l}{ Substandard compost } & $11(14.4)$ & $0(0)$ & & $8(14.0)$ \\
\hline
\end{tabular}

Table 4. Chemical properties of composts by the raw materials.

\begin{tabular}{|c|c|c|c|c|c|c|c|c|c|c|c|c|}
\hline Raw material ${ }^{\ddagger}$ & OM & OM/N & T-N & $\mathrm{P}_{2} \mathrm{O}_{5}$ & $\overline{\mathrm{K}_{2} \mathrm{O}}$ & $\mathrm{CaO}$ & $\mathrm{MgO}$ & $\mathrm{Na}_{2} \mathrm{O}$ & $\mathrm{NaCl}$ & $\mathrm{Cu}$ & $\mathrm{Zn}$ & Water \\
\hline & $\%$ & & ------. & ------ & 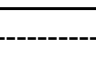 & $-\%$ & - & - & ------ & \multicolumn{2}{|c|}{--- $\mathrm{mg} \mathrm{kg}^{-1}$--- } & $\%$ \\
\hline $\mathrm{P}$ & $39.6^{\mathrm{ns \dagger}}$ & $32.7^{\mathrm{ab}}$ & $1.30^{\mathrm{b}}$ & $1.63^{\mathrm{ns}}$ & $1.22^{\mathrm{ns}}$ & $2.69^{\mathrm{cd}}$ & $0.69^{\mathrm{ns}}$ & $0.24^{b}$ & $0.46^{\mathrm{c}}$ & $84^{\mathrm{ns}}$ & $287^{\mathrm{ns}}$ & $46.0^{\mathrm{a}}$ \\
\hline $\mathrm{Ch}$ & 41.1 & $26.2^{\mathrm{c}}$ & $1.63^{\mathrm{b}}$ & 2.10 & 1.63 & $5.85^{\mathrm{a}}$ & 1.33 & $0.23^{\mathrm{b}}$ & $0.44^{\mathrm{c}}$ & 47 & 222 & $34.2^{\mathrm{ab}}$ \\
\hline $\mathrm{P}+\mathrm{Ch}$ & 40.3 & $27.9^{\mathrm{bc}}$ & $1.47^{\mathrm{b}}$ & 1.99 & 1.40 & $4.31^{\mathrm{abc}}$ & 0.92 & $0.27^{\mathrm{b}}$ & $0.49^{\mathrm{c}}$ & 80 & 306 & $40.2^{\mathrm{ab}}$ \\
\hline $\mathrm{P}+\mathrm{Ca}$ & 45.5 & $34.2^{\mathrm{ab}}$ & $1.34^{\mathrm{b}}$ & 1.57 & 1.87 & $1.99^{\mathrm{d}}$ & 0.81 & $0.47^{\mathrm{a}}$ & $0.89^{\mathrm{a}}$ & 86 & 444 & $38.8^{\mathrm{ab}}$ \\
\hline $\mathrm{P}+\mathrm{Ch}+\mathrm{Ca}$ & 40.9 & $35.4^{\mathrm{a}}$ & $1.17^{\mathrm{b}}$ & 1.76 & 1.45 & $4.12^{\mathrm{bc}}$ & 1.07 & $0.31^{\mathrm{ab}}$ & $0.59^{b c}$ & 83 & 269 & $41.3^{\mathrm{a}}$ \\
\hline $\mathrm{Li}+\mathrm{O}$ & 48.3 & $22.6^{\mathrm{c}}$ & $2.27^{\mathrm{a}}$ & 2.29 & 1.57 & $5.48^{\mathrm{ab}}$ & 1.00 & $0.46^{\mathrm{a}}$ & $0.76^{\mathrm{ab}}$ & 68 & 261 & $28.3^{\mathrm{b}}$ \\
\hline
\end{tabular}

${ }^{\dagger}$ Values within a column followed by the same letter are not significant at $5 \%$ level by DMRT test.

${ }^{\ddagger} \mathrm{P}$; pig feces, Ch; chicken feces, Ca; cattle feces, Li; livestock feces, O; oil cake.

degree was $33.3 \%$, the second grade $40.4 \%$, the third grade $7.0 \%$, general compost grade $5.3 \%$, and substandard one $14.0 \%$. Only 4 composts out of 9 ones (44.4\%) made by farming guilds met the LQS and their quality was distributed evenly as $22.2 \%$ in each first, second and general compost degree, respectively and $33.3 \%$ in substandard one (Table. 3).

$\mathrm{OM} / \mathrm{N}$ declined in the composts made from chicken feces and oil cake because of their high $\mathrm{N}$ content. $\mathrm{Ca}$ content increased by the addition of chicken feces and $\mathrm{NaCl}$ by adding cattle feces, while water content decreased in the composts mixed with oil cake due to the need of low water content to enable the compost to be formed in a pellet shape (Table. 4).

Pig and chicken feces were mainly used as the raw materials of commercialized livestock feces composts, while cattle feces occupied only a small part. This seems to be caused by the low nutrient content of cattle feces and resultant safety in private use as a soil ameliorator. The average contents of $\mathrm{N}, \mathrm{P}_{2} \mathrm{O}_{5}$ and $\mathrm{K}_{2} \mathrm{O}$ were 1.5 , 2.0 and $1.5 \%$, respectively. This result implies that $\mathrm{P}_{2} \mathrm{O}_{5}$ content in both compost and soil was most important factors when the compost application rate was determined as reported by Kim et al. (2000) and Jakob et al. (2002). Compost quality by manufacturer was better in the order of farmer's cooperative society $>$ civil $>$ farming guild. This seems to be derived from the fact that farmer's cooperative society generally has fine financing and facilities together with a sense of responsibility, and civil operators have abundant experience and know-how. Many farming guilds, however, are organized to get the subsidy or financial support from government and the operators were relatively less experienced. The result of chemical properties of composts by the source of raw materials may be useful when manufacturer tries to adjust the mixing ratio of the raw materials for improving their compost quality.

\section{Conclusion}

The proportion of the main raw materials of surveyed compost products was in the order of chicken feces $29.2 \%$, pig+chicken feces $23.1 \%$, pig feces $20.0 \%$, livestock feces+oil cake $12.3 \%$, pig+chicken+cattle feces $10.8 \%$ and pig+cattle feces $4.6 \%$. Chemical properties of 76 livestock feces composts produced in Gyeonggi Province in 2008 were as follows; OM $41.8 \pm 7.8 \%$, $\mathrm{OM} / \mathrm{N} 29.2 \pm 7.5$, T-N $1.53 \pm 0.51 \%, \mathrm{P}_{2} \mathrm{O}_{5} 1.98 \pm 0.81 \%$, $\mathrm{K}_{2} \mathrm{O} 1.46 \pm 0.57 \%, \mathrm{CaO} 4.48 \pm 1.95 \%, \mathrm{NaCl} 0.87 \pm$ $0.41 \%$ and water $37.9 \pm 11.6 \%$. Compost quality score 
was $16.0 \pm 2.8$ and the first grade compost was $34.2 \%$, the second grade $39.5 \%$, the third grade $5.3 \%$, general compost grade $6.6 \%$ and substandard grade $14.4 \%$, respectively. $\mathrm{OM} / \mathrm{N}$ was lower in chicken and oil cake composts, while $\mathrm{CaO}$ content was higher in chicken compost and $\mathrm{NaCl}$ in cattle compost. $\mathrm{Cu}$ and $\mathrm{Zn}$ were tended to be high in pig compost.

\section{References}

Jakob, M. and S.J. Lars. 2002. The production and use of animal manures p. 16-36. In S.J. Lars et al. (ed.) Plant nutrition soil fertility fertilizers and fertilization (4th ed.), The Royal Veterinary \& Agricultural University, Copenhagen.

Jeon, W.T., C.Y. Park, Y.S. Cho, K.D. Park, E.S. Yun, U.G. Kang, S.T. Park, and Z.R. Choe. 2003. Spatial distribution of rice root under long-term chemical and manure fertilization in paddy. Korean J. Soil Sci. Fert. 48:484-489.

Jo, I.H. and J.S. Lee. 2001. Effects of application of nightsoil sludge compost of dry matter yields and nutritive value of orchard grass (Dactylis glomerata L.). Korean Journal of Organic Agriculture. 9:37-49.

Jung, Y.K. 2002. Changes in the soil properties, vigor at early growth, yields, and mineral nutrients of forages as affected by compost application. J. Korean Grassl. Sci. 22:69-76.

Kim, J.G. and K.Y Jung. 2000. Amount of maximum compost application on the long term application with different organic material sources in upland soil. Korean J. Soil Sci. Fert. 33:182-192.

Lee, S.M., I.S. Ryu, C.S. Lee, Y.H. Park, and M.H. Um. 1999. Determination of application rate of composted pig manure for wetland rice. Korean J. Soil Sci. Fert. 32:182-191.

Shayya, W.H., R.V. Bernuth, J.T. Ritchie, and H.L. Person. 1993. A simulation model for land application of animal manure. American Society of Agricultural Engineers. 93:26

Song, Y.S., H.K. Kwak, B.K. Hyun, and P.J. Kim. 2001. Effects of composted pig manure on rice cultivation in paddy soils of different texture. Korean J. Soil Sci.Fert. 34:265-272.

Yang, C.H., B.S. Kim, C.H. Yoo, W.K. Park, Y.S. Yoo, J.D. Kim, and K.Y. Jung. 2007. Composting impacts on soil properties and productivity in a fluvio-marine deposit paddy field. Korean J. Soil Sci. Fert. 40:181-188.

Yun, B.K., P.K. Jung, S.J. Oh, S.K. Kim, and I.S. Ryu. 1996. Effects of compost application on soil loss and physico-chemical properties in lysimeters. Korean J. Soil Sci. Fert. 29:336-341. 